\title{
ANALISIS DAYA SAING DAN FAKTOR PENENTU EKSPOR KOMODITAS UNGGULAN INDONESIA KE ORGANISASI KERJASAMA ISLAM (OKI)
}

\author{
Deki Sunardi $^{1}$, Rina Oktaviani ${ }^{2}$, Tanti Novianti ${ }^{2}$ \\ ${ }^{1}$ Mahasiswa Magister Program Studi Ilmu Ekonomi, FEM IPB \\ ${ }^{2}$ Staf Pengajar FEM IPB
}

Artikel diterima Juni 2014

Artikel disetujui untuk dipublikasikan Desember 2014

\begin{abstract}
Organization of Islamic Cooperation or OIC is an association of Islamic countries in the world which is made up of 57 countries, including Indonesia. OIC has great potential as a destination for the export market. The purpose of this study is to analyze the competitiveness of Indonesian exports to OIC and determinants that influence it. Competitiveness of commodities analyzed using the RCA, IIT and EPD, while the determinants of export using the gravity model analysis. The results showed that 86,7 percent from fifteen commodities that have the largest export value had RCA more than one and seven commodity have market position as rising star, but from IIT analysis showed that integration of economics still not strong enough. Factors that influence a positive and significant impact on Indonesia's commodity exports to OIC are per capita income, real exchange rate and a common language, while the negative effects are the gdp per capita difference, economic distance and tarrif.
\end{abstract}

Key words: RCA, IIT, EPD, Gravity Model

\section{PENDAHULUAN}

Perdagangan merupakan salah satu ujung tombak dalam perekonomian suatu negara, terutama bagi negara yang menganut sistem ekonomi terbuka. Keterbukaan perekonomian membuat perpindahan barang dan jasa semakin cepat, sehingga mendorong terciptanya arus globalisasi yang tidak dapat dibendung lagi. Dalam persaingan perdagangan internasional, negaranegara di dunia sangat mengandalkan ekspor untuk meningkatkan perekonomiannya. Ekspor akan mempengaruhi laju perekonomian di dalam negeri, dimana dengan tingginya ekspor akan menarik investasi baik dari luar maupun dalam negeri, sehingga akan meningkatkan peluang terciptanya lapangan kerja.

Pertumbuhan ekspor dapat dicapai dengan memaksimalkan potensi yang ada baik dari sektor migas maupun non migas. Pada sektor migas, Indonesia memiliki keunggulan untuk mengekspor gas bumi, karena Indonesia memiliki gas alam yang sangat melimpah. Sedangkan pada sektor non migas, Indonesia memiliki berbagai macam komoditas yang dapat bersaing di dunia internasional, seperti minyak kelapa sawit, tekstil, elektronik, produk karet, otomotif dan lain-lain. Neraca perdagangan Indonesia saat ini 
mengalami permasalahan, terutama pada sisi migas yang cenderung mengalami defisit akibat tingginya impor bahan bakar minyak bumi. Pada tahun 2012, defisit neraca perdagangan sektor migas mencapai US\$ 5.5 miliar. Sebaliknya, pada sektor non migas, neraca perdagangan Indonesia mengalami peningkatan dalam lima tahun terakhir. Pada periode tahun 2008 sampai 2012, sektor non migas mengalami surplus dengan trend 12.83 persen (Kemendag, 2013).

Sasaran pasar ekspor non migas Indonesia tersebar ke berbagai negara di dunia. Selama ini, pasar tujuan ekspor non migas Indonesia masih didominasi oleh kelompok mitra dagang utama yaitu Tiongkok, Jepang, Amerika Serikat, India dan Singapura. Pada tahun 2012, pangsa pasar ekspor non migas ke Tiongkok mencapai 12.88 persen dari seluruh total ekspor Indonesia ke dunia dengan nilai ekspor sebesar US\$ 20.8 miliar. Pangsa pasar ekspor ke Jepang mencapai 10.64 persen, Amerika Serikat 9.01 persen, India 7.68 persen dan Singapura 6.51 persen.

Ketergantungan terhadap suatu pasar tertentu dapat menimbulkan dampak negatif. Ekspor komoditas yang masih bergantung pada pasar tradisional sangat beresiko bagi perkembangan ekspor Indonesia itu sendiri, terutama jika terjadi guncangan ekonomi dunia. Hal ini bisa terlihat pada tahun 2008 ketika terjadi krisis di Amerika Serikat yang berdampak terhadap sebagian besar ekonomi negara di dunia tak terkecuali Indonesia. Krisis ini menyebabkan ekspor non migas mengalami pelambatan di lima negara mitra dagang utama. Oleh karena itu, untuk mempertahankan kinerja perdagangan, maka perlu dilakukan suatu diversifikasi terhadap pasar tujuan maupun pada komposisi produk ekspor.
Salah satu diversifikasi pasar yang dapat dilakukan yaitu melalui peningkatan eskpor ke Organisasi Kerjasama Islam (OKI). OKI merupakan salah satu organisasi terbesar kedua setelah Perserikatan Bangsa-Bangsa (PBB) dari segi jumlah anggota. Saat ini OKI beranggotakan 57 negara yang mayoritas penduduknya adalah muslim. Indonesia merupakan anggota OKI sejak organisasi ini pertama kali berdiri. Melihat jumlah negara yang sangat banyak, OKI merupakan pasar yang sangat potensial bagi Indonesia. OKI didirikan di Rabat, Maroko pada tanggal 25 September 1969. Organisasi ini adalah organisasi non militer yang berdiri karena dipicu oleh peristiwa pembakaran mesjid alaqsa pada tanggal 21 Agustus 1969.

Potensi OKI dapat dilihat dari segi jumlah populasi dan ekonominya. Jumlah penduduk OKI mencapai 22.6 persen dari seluruh populasi dunia yaitu sekitar 1,5 miliar orang. Dari segi ekonomi, total Pendapatan Domestik Bruto (PDB) OKI pada tahun 2004 sekitar US\$ 2.3 triliun dan meningkat hingga US\$ 6.5 triliun pada tahun 2012. Share PDB OKI pada tahun 2012 ini mencapai 9.01 persen dari PDB dunia (Gambar 1).

Perdagangan Indonesia dengan OKI didominasi oleh sektor migas dan non migas. Pada periode tahun 2009 sampai 2013, neraca perdagangan Indonesia dan OKI berada dalam posisi defisit. Hal ini terjadi karena Indonesia masih mengimpor minyak bumi dan gas dalam jumlah besar dari negara-negara anggota OKI seperti Azerbaijan, Brunai Darussalam, Iran, Kuwait, Malaysia, Qatar, Saudi Arabia dan Uni Emirat Arab. Namun dari sisi lain, ekspor non migas Indonesia mengalami peningkatan yang positif dan signifikan setiap tahunnya. Hal ini mengindikasikan bahwa negara-negara 
OKI semakin memiliki ketergantungan

produk-produk dari Indonesia.

dan adanya kebutuhan terhadap

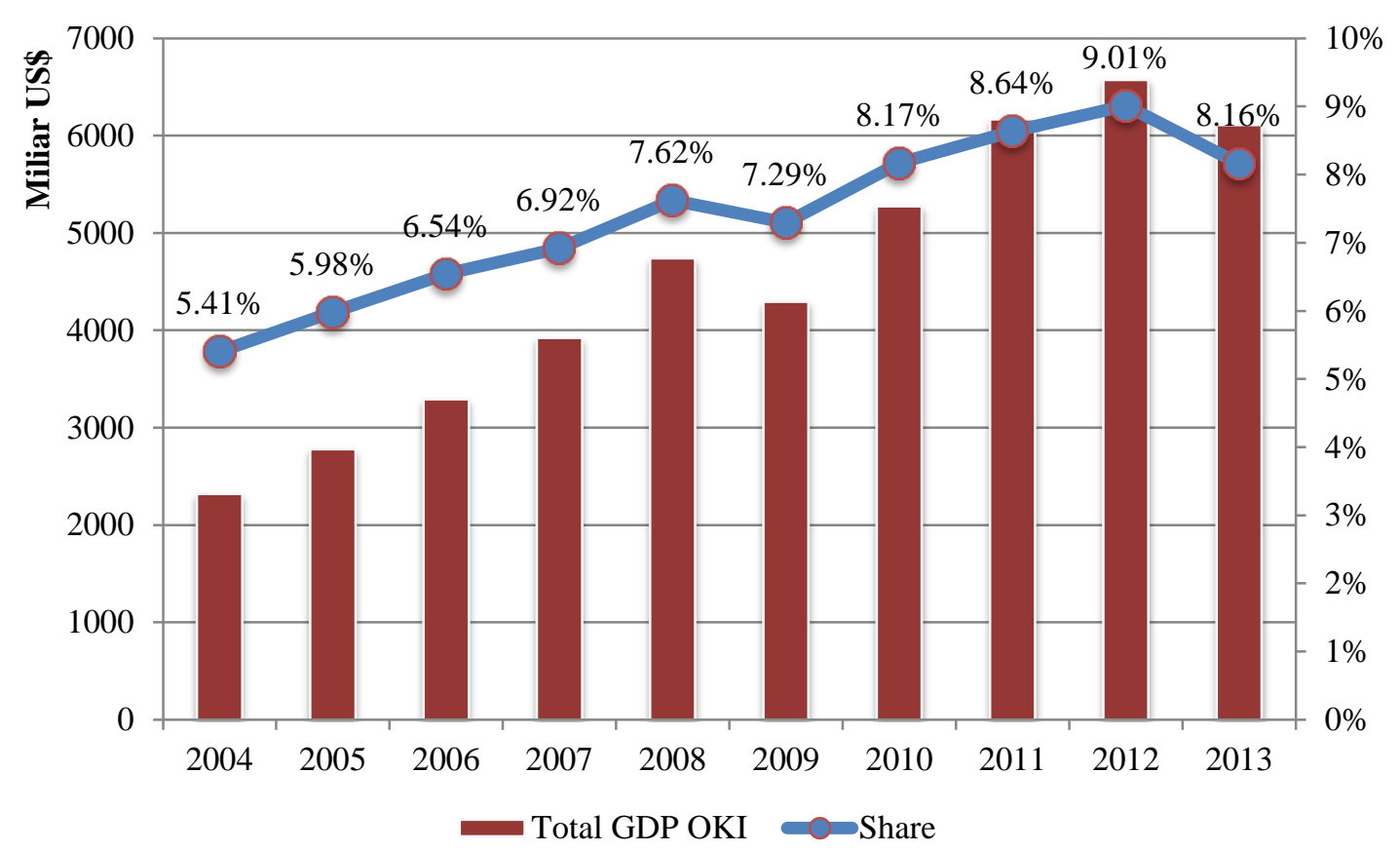

Gambar 1 Total dan share PDB OKI terhadap PDB dunia Tahun 2004-2013

Dalam upaya diversifikasi pasar dan produk ekspor untuk meningkatkan kinerja perdagangan, serta adanya rencana OKI dalam jangka panjang untuk membentuk pasar bersama Islam (Islamic Common Market), maka kajian mengenai kondisi perdagangan dan kinerja komoditi ekspor yang berdaya saing perlu dilakukan. Oleh karena itu, penelitian ini memiliki tujuan sebagai berikut :

1. Menganalisis potensi ekonomi negara OKI sebagai pasar tujuan ekspor.

2. Menganalisis kinerja perdagangan berdasarkan daya saing dan tingkat integrasi komoditas unggulan Indonesia ke OKI.

3. Menganalis faktor-faktor penentu ekspor komoditas unggulan Indonesia ke negara-negara anggota OKI.

\section{METODE PENELITIAN}

Data yang akan digunakan dalam penelitian ini adalah data sekunder yang berasal dari berbagai sumber. Data aliran perdagangan yang meliputi ekspor maupun impor komoditi dari Indonesia dan negara-negara OKI akan diambil dari beberapa sumber yang saling melengkapi seperti Kementerian Perdagangan, Worldbank maupun Trademap. Data perdagangan yang akan diteliti adalah seluruh komoditi dengan kode HS 4 digit. Kode HS 4 digit digunakan agar lebih mempermudah untuk melihat secara lebih detail komoditi yang menjadi andalan ekspor Indonesia ke OKI. Beberapa penelitian menunjukkan bahwa pengambilan kode HS 4 digit dilakukan untuk memperoleh hasil yang mendekati sebenarnya, tidak overestimate maupun underestimate. Untuk data-data makro seperti 
pendapatan per kapita dan nilai tukar riil akan diambil dari website Worldbank, sedangkan data-data terkait dengan model gravitasi seperti jarak dan dummy variabel kesamaan bahasa akan diambil dari website CEPII (Centre d'Etudes Prospectives et d'Informations Internationales). Variabel tarif impor yang diterapkan oleh negara-negara OKI sebagai tujuan ekspor komoditas unggulan Indonesia akan diambil dari website WTO (World Trade Organization) dengan satuan persentase. Rincian data yang digunakan dapat dilihat pada Tabel 1.

Tabel 1 Jenis dan sumber data

\begin{tabular}{clcc}
\hline No & \multicolumn{1}{c}{ Jenis Data } & Sumber & Keterangan \\
\hline 1 & Data ekspor nominal & WITS/Trademap/BPS/ & US\$ \\
2 & $\begin{array}{l}\text { Pemendapatan per } \\
\text { nominal }\end{array}$ & Worldbank & US\$/tahun \\
3 & Nilai tukar riil & Worldbank & Rp/mata uang negara partner \\
4 & Jarak ekonomi & CEPII dan Worldbank & km \\
5 & Bahasa & CEPII & 1 apabila bahasanya mirip \\
& & WTO & dgn Indonesia; 0 sebaliknya \\
6 & Tarif & & Persen \\
\hline
\end{tabular}

\section{Metode Analisis}

Analisis kinerja perdagangan digunakan untuk mengetahui beberapa hal, diantaranya yaitu untuk mengetahui berapa banyak suatu negara melakukan perdagangan dengan negara lain dilihat dari segi volume ataupun nilai ekspor impor negara tersebut. Dengan melakukan analisis pada kinerja perdagangan, juga dapat diketahui komoditas apa saja yang selama ini diperdagangkan serta dengan negara mana saja Indonesia melakukan aktivitas perdagangannya, apakah dengan semua negara anggota tersebut atau hanya dengan beberapa anggota saja.

Metode yang akan digunakan adalah metode analisis secara deskriptif dan kuantitatif. Metode deskriptif digunakan untuk melihat pola perdagangan Indonesia dengan OKI dan juga melihat komoditas apa saja yang selama ini menjadi produk ekspor unggulan dari Indonesia. Sedangkan metode secara kuantitatif menggunakan tiga alat analisis yaitu Revealed
Comparative Advantage (RCA), Intra Industry Trade (IIT) dan Export Product Dynamics (EPD).

\section{Analisis Revealed Comparative Advantage (RCA)}

Analisis RCA digunakan untuk mengidentifikasi sektor atau komoditi suatu negara yang memiliki daya saing. Keunggulan komparatif dapat terlihat dari hasil analisis RCA. Nilai RCA dihitung dengan menggunakan rumus matematis yang diperkenalkan oleh Balassa dalam Esterhuizen (2006) yang telah dimodifikasi seperti berikut ini :

keterangan :

$$
R C A_{i j}=\frac{X_{i k} / X_{i}}{X_{a k} / X_{a}}
$$

- $X_{i k}$ : Nilai ekspor Indonesia untuk komoditi k ke OKI

- $X_{i}$ : Nilai total ekspor Indonesia ke OKI

- $X_{a k}$ : Nilai ekspor dunia komoditi k ke OKI

- $X_{a}$ : Nilai total ekspor dunia ke OKI 
Nilai RCA yang berada diatas angka satu mengidentifikasikan bahwa suatu produk memiliki keunggulan atau daya saing. Sebaliknya, apabila nilai RCA dibawah satu, maka daya saing produk tersebut sangat rendah. Semakin tinggi nilai RCA, menunjukkan daya saing suatu produk semakin tinggi.

\section{Analisis Intra Industry Trade (IIT)}

Setelah diketahui komoditi yang memiliki daya saing ke negara OKI, maka langkah selanjutnya adalah melakukan analisis Intra Industry Trade (IIT) untuk mengetahui tingkat integrasi perdagangan antar negara dalam suatu industri atau sektor tertentu. Metode pengukuran yang paling umum digunakan adalah dengan menggunakan Grubel-Llyod indeks yang telah disesuaikan berdasarkan Sharma (2004), sebagai berikut :

$$
G L_{k}^{i j}=1-\frac{\left|X_{k}^{i j}-M_{k}^{i j}\right|}{X_{k}^{i j}+M_{k}^{i j}} \times 100
$$

keterangan :

- $X_{k}^{i j}$ : ekspor negara i ke negara $\mathrm{j}$ pada komoditi/sektor $\mathrm{k}$

- $\quad M_{k}^{i j}$ : impor negara i ke negara j pada komoditi/sektor $\mathrm{k}$

Nilai GL indeks berkisar antara 0 sampai 100. Jika dalam satu komoditi, suatu negara hanya sebagai pengekspor atau pengimpor saja, maka indeks GL akan bernilai nol, dalam hal ini perdagangan hanya berlangsung dalam satu arah saja. Sebaliknya, jika dua negara melakukan ekspor dan impor dengan jumlah yang sama dalam suatu komoditi atau sektor tertentu, nilai indeks GL akan bernilai 100. Penjelasan lebih detail tentang intra industry trade sebagai indikator integrasi perdagangan terlihat pada Tabel 2.

Tabel 2 Klasifikasi Intra Industry Trade (IIT)

\begin{tabular}{|c|c|}
\hline Intra Industry Trade (IIT) & Klasifikasi \\
\hline$*$ & Tidak terdapat aliran perdagangan \\
\hline 0.00 & Tidak ada integrasi (Perdagangan satu arah) \\
\hline$>0.00-24.99$ & Integrasi lemah \\
\hline $25.00-49.99$ & Integrasi sedang \\
\hline $50.00-74.99$ & Integrasi kuat \\
\hline $75.00-99.99$ & Integrasi sangat kuat \\
\hline
\end{tabular}

Sumber : Austria (2004)

\section{Analisis Export Product Dynamics (EPD)}

Salah satu indikator yang baik untuk mengetahui tingkat daya saing adalah Export Product Dynamics (EPD). Indikator EPD digunakan untuk mengidentifikasi posisi pasar suatu komoditi pada tujuan pasar tertentu dan juga untuk mengetahui performa komoditi tersebut, apakah memiliki pertumbuhan yang dinamis dalam arti pertumbuhannya cepat atau tidak.
Sebuah matriks EPD terdiri atas daya tarik pasar dan informasi kekuatan bisnis. Daya tarik pasar dihitung berdasarkan pertumbuhan dari permintaan sebuah produk untuk tujuan pasar tertentu, sedangkan informasi kekuatan bisnis diukur berdasarkan pertumbuhan dari perolehan pasar (market share) sebuah negara pada tujuan pasar tertentu. Meskipun suatu komoditi memiliki nilai ekspor yang tinggi, tetapi belum tentu komoditi 
tersebut memiliki pertumbuhan ekspor yang cepat dari tahun ke tahunnya, sehingga komoditi yang memiliki laju pertumbuhan yang cepat patut diperhitungkan sebagai komoditi potensial negara tersebut.

Analisis EPD yang terdiri dari kombinasi daya tarik pasar dan kekuatan bisnis menghasilkan karakter posisi yang terbagi menjadi empat kategori yaitu Rising Star, Falling Star, Lost Opportunity dan Retreat. Posisi pasar ideal dari empat karakter tersebut adalah pada posisi Rising Star yang ditandai dengan negara tersebut memperoleh tambahan pangsa pasar untuk produk-produk yang berkembang cepat (fast growing products). Lost opportunity terkait dengan penurunan pangsa pasar pada produk-produk yang dinamis dan merupakan posisi yang paling tidak diinginkan. Falling star juga merupakan posisi yang tidak diinginkan, tetapi masih lebih baik dari lost opportunity dikarenakan pangsa pasarnya masih tetap meningkat. Sementara itu retreat biasanya tidak diinginkan, tetapi pada kasus tertentu mungkin diinginkan jika pergerakannya menjauhi produk-produk yang stagnan dan menuju produk-produk yang dinamis (Bappenas, 2009). Secara lengkap matriks EPD, terlihat pada tabel di bawah ini :

Tabel 3 Matriks EPD

\begin{tabular}{ccc}
\hline \multirow{2}{*}{ Share of Country's Export in OIC Trade } & \multicolumn{2}{c}{ Share of Product in OIC Trade } \\
\cline { 2 - 3 } & Rising (Dynamic) & Falling (Stagnant) \\
\hline Rising (Competitive) & Rising Star & Falling Star \\
\hline Falling (Non-Competitive) & Lost Opportunity & Retreat \\
\hline
\end{tabular}

Sumber : Estherhuizen (2006)

Tabel matriks EPD diatas dapat dikonversikan ke dalam bentuk gambar berbentuk kuadran dengan sumbu $\mathrm{X}$ menggambarkan peningkatan pangsa pasar ekspor di perdagangan dunia atau daya tarik pasar dan sumbu $\mathrm{Y}$ yang menggambarkan peningkatan pangsa pasar produk i di perdagangan dunia atau informasi kekuatan bisnis.

Secara matematis untuk menghitung pangsa pasar ekspor suatu negara (negara i) dan pangsa pasar suatu produk (produk $\mathrm{n}$ ) dalam perdagangan dunia adalah sebagai berikut :

Sumbu X : Pertumbuhan pangsa pasar ekspor i $($ Indonesia $)=$

$\frac{\sum_{t=1}^{t}\left(\frac{X_{i n}}{X_{n}}\right)_{t} \times 100 \%-\sum_{t=1}^{t}\left(\frac{X_{i n}}{X_{n}}\right)_{t-1} \times 100 \%}{T}$
Sumbu Y : Pertumbuhan pangsa pasar produk $\mathrm{n}=$

$\frac{\sum_{t=1}^{t}\left(\frac{X_{n}}{X}\right)_{t} \times 100 \%-\sum_{t=1}^{t}\left(\frac{X_{n}}{X}\right)_{t-1} \times 100 \%}{T}$

dimana :

$$
\begin{array}{ll}
X & : \text { Nilai ekspor } \\
T & \text { : Jumlah tahun } \\
t & : \text { tahun ke- } t
\end{array}
$$

\section{Analisis Model Gravitasi}

Metode yang digunakan untuk menganalisis faktor penentu ekspor komoditi unggulan Indonesia ke OKI menggunakan model gravitasi statis. Spesifikasi model yang akan digunakan mengacu kepada penelitian yang dilakukan oleh Nguyen (2010) yang telah dimodifikasi yaitu sebagai berikut: 


$$
\begin{aligned}
\ln \left(X_{i j t}\right)= & \beta_{0}+\beta_{1} \ln \left(P D B C A P_{i t}\right)+\beta_{2} \ln \left(P D B C A P_{j j}\right)+\beta_{3} \ln \left(P D B C A P D_{i j t}\right)+ \\
& \beta_{4} \ln \left(R E R_{i j t}\right)+\beta_{5} \ln \left(E C O D I S T_{i j t}\right)+\beta_{6} T r f_{j t}+\beta_{7} \text { Lang }_{i j}+e_{i j t}
\end{aligned}
$$

keterangan :

- $X_{i j t}$ : Nilai ekspor komoditi unggulan Indonesia ke negara $\mathrm{j}$ pada tahun $\mathrm{t}$

- $P D B C A P_{i t}$ : PDB per kapita negara Indonesia pada tahun $\mathrm{t}$

- $P D B C A P_{j t}$ : PDB per kapita negara $\mathrm{j}$ pada tahun $\mathrm{t}$

- $P D B C A P D_{i j t}$ : Perbedaan pendapatan per kapita negara Indonesia dan negara $\mathrm{j}$

- $R E R_{i j t}$ : Nilai tukar riil antara negara Indonesia dan negara j pada tahun $\mathrm{t}$

- ECODIST $T_{i j t}$ : Jarak ekonomi antara Indonesia dengan negara $\mathrm{j}$ pada tahun $\mathrm{t}$

- $\quad \operatorname{Tr} f_{j t}$ : Tarif negara j pada tahun $\mathrm{t}$

- Lang $_{i j}$ :Dummy variabel perbedaan bahasa antara Indonesia dan negara $\mathrm{j}$

- $e_{i j t}$ : Error term

\section{Definisi Variabel Operasional}

Penjelasan mengenai variabel-
variabel yang digunakan dalam penelitian ini antara lain :

1. Nilai ekspor $(\mathrm{X})$ adalah nilai perdagangan dari suatu negara ke negara mitra dagangnya.

2. PDB Perkapita merupakan pengukuran terhadap besaran pendapatan rata-rata penduduk dalam suatu negara. PDB percapita adalah hasil pembagian dari pendapatan nasional (PDB) dengan jumlah penduduk.

3. Perbedaan pendapatan per kapita (GDP percapita differencing) merupakan hasil perhitungan dari perbedaan pendapatan absolut antar dua negara.

$$
\begin{aligned}
P^{P B C A P D_{i j}} & \\
& =\mid \ln \frac{P D B_{i}}{P O P_{i}} \\
& -\ln \frac{P D B_{j}}{P O P_{j}} \mid
\end{aligned}
$$

4. Nilai tukar riil (RER) adalah harga relatif dari barang-barang yang diperdagangkan antar dua negara. Secara umum nilai tukar riil didapatkan dari hasil perkalian nilai tukar nominal dengan rasio tingkat harga yang biasanya diukur dari Indeks Harga Konsumen (IHK).

$$
R E R=e \times \frac{\text { IHK pengimpor }}{\text { IHK pengekspor }}
$$

5. Jarak ekonomi (ECODIST) merupakan proksi dari biaya transportasi yang diperlukan dalam transaksi perdagangan antar negara yang dipisahkan oleh jarak geografis. Semakin jauh jarak suatu negara dengan negara lainnya mengindikasikan biaya transportasi yang semakin tinggi. Jarak ekonomi didapatkan dengan rumus :

$$
\text { ECODIST }=\frac{\text { jarak geografis }}{G D P_{j} / G D P_{w}}
$$

6. Tarif adalah pungutan yang dikenakan terhadap barang yang diperdagangkan ketika masuk atau keluar lintas batas teritorial suatu negara. 


\section{Uji Statistika}

Uji statistika dilakukan terhadap hasil dari data panel. Data panel sendiri merupakan data gabungan antara data runtun waktu (time series) dengan data silang (cross section). Data runtun waktu merupakan data dari satu objek/individu tetapi memiliki beberapa periode waktu yang berbeda, sedangkan data silang terdiri dari beberapa atau banyak objek/individu dalam suatu periode waktu tertentu. Data panel memiliki beberapa keuntungan dibandingkan dengan data time series atau cross section diantaranya yaitu data yang terbentuk akan lebih banyak karena merupakan data gabungan, sehingga akan menghasilkan degree of freedom yang lebih besar yang akan memperkecil efek bias.

Dalam analisis data panel, terdapat tiga teknik estimasi regresi yaitu model dengan metode Pooled Least Squares, model fixed effect dan model random effect. Untuk melakukan pemilihan model yang efisien, maka perlu dilakukan pengujian statistika terhadap ketiga model data panel tersebut. Diagram pemilihan model terbaik dalam data panel terlihat pada Gambar 5.

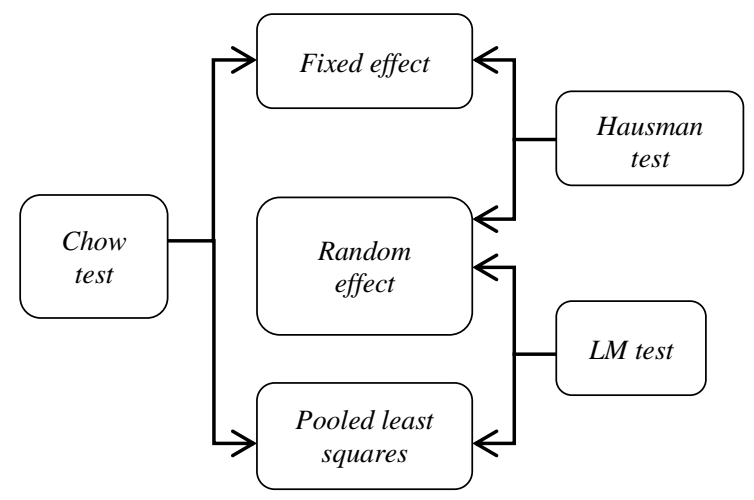

Gambar 2 Pengujian model data panel

1. Chow test

Uji chow atau pengujian $F$ statistik dilakukan untuk memilih model yang terbaik antara Pooled least squares dengan fixed effect. Hipotesa yang digunakan adalah sebagai berikut :

$\mathrm{H}_{0}$ : Model Pooled least squares

$\mathrm{H}_{1}$ : Model Fixed effect

Dasar penolakan terhadap hipotesa nol $\left(\mathrm{H}_{0}\right)$ adalah dengan menggunakan F-statistik sebagai berikut :

$$
F_{N-1, N T-N-K}=\frac{\left(E S S_{1}-E S S_{2}\right) /(N-1)}{E S S_{2} /(N T-N-K)}
$$

keterangan:

- $\mathrm{ESS}_{1}$ adalah Residual Sum Square hasil pendugaan Pooled least squares

- $\mathrm{ESS}_{2}$ adalah Residual Sum Square hasil pendugaan Fixed effect

- $\mathrm{N}$ adalah jumlah data cross section

- T adalah jumlah data time series

- $\mathrm{K}$ adalah jumlah variabel penjelas

Statistik Chow Test mengikuti distribusi F-statistik dengan derajat bebas (N-1,NT-N-K) jika nilai Chow Statistik (F-Stat) hasil pengujian lebih besar dari Ftabel, maka cukup bukti untuk menolak hipotesa nol sehingga model yang digunakan adalah model fixed effect, dan begitu juga sebaliknya.

2. Hausman test

Dalam memilih apakah fixed effect atau random effects yang lebih baik, maka uji dilakukan uji Hausman. Dalam uji ini dirumuskan hipotesis sebagai berikut :

$\mathrm{H}_{0}$ : Model Random effect

$\mathrm{H}_{1}$ : Model Fixed effect

Sebagai dasar penolakan Ho maka digunakan statistik Hausman dan membandingkannya dengan Chi square. Statistik Hausman dirumuskan dengan : 


$$
\begin{aligned}
& \quad H=\left(\beta_{R E M}-\beta_{F E M}\right)^{\prime}\left(M_{F E M}-\right. \\
& \left.M_{R E M}\right)^{-1}\left(\beta_{R E M}-\beta_{F E M}\right) \sim \chi^{2(k)} \\
& \text { keterangan: }
\end{aligned}
$$

- M adalah matriks kovarians untuk parameter $\beta$

- $\mathrm{k}$ adalah degrees of freedom Jika nilai $H$ hasil pengujian lebih besar dari $\chi^{2}$ tabel, maka cukup bukti untuk melakukan penolakan terhadap Ho, sehingga model yang digunakan adalah model fixed effect, begitu juga sebaliknya.

\section{HASIL DAN PEMBAHASAN}

Potensi ekonomi negara-negara OKI dapat dilihat dari Pendapatan
Domestik Bruto (PDB) yang merupakan cerminan dari tingkat pendapatan masyarakat suatu negara. Tabel 2 merupakan tingkat pendapatan serta pertumbuhan ekonomi tahunan negaranegara anggota OKI yang menjadi pasar tujuan ekspor utama Indonesia. Turki menjadi negara yang memiliki PDB tertinggi dengan nilai US\$ 820207 juta dan pertumbuhan ekonomi sebesar 4 persen. Secara umum tingkat pendapatan negara-negara OKI memiliki pertumbuhan yang positif yang dapat menjadi indikator sebagai

\begin{tabular}{|c|c|c|c|c|c|}
\hline Negara & 2009 & 2010 & 2011 & 2012 & 2013 \\
\hline Bangladesh & $\begin{array}{c}89357 \\
(5.7)\end{array}$ & $\begin{array}{c}100360 \\
(6.1)\end{array}$ & $\begin{array}{c}111906 \\
(6.7)\end{array}$ & $\begin{array}{c}116034 \\
(6.2)\end{array}$ & $\begin{array}{c}129857 \\
(6.0)\end{array}$ \\
\hline Egypt & $\begin{array}{c}188984 \\
(4.7)\end{array}$ & $\begin{array}{c}218888 \\
(5.1)\end{array}$ & $\begin{array}{c}236001 \\
(1.8)\end{array}$ & $\begin{array}{c}262832 \\
(2.2)\end{array}$ & $\begin{array}{c}271973 \\
(2.1)\end{array}$ \\
\hline Iran & $\begin{array}{c}362661 \\
(3.9)\end{array}$ & $\begin{array}{c}422568 \\
(5.9)\end{array}$ & $\begin{array}{c}528426 \\
(3.0)\end{array}$ & $\begin{array}{c}502729 \\
(3.0)\end{array}$ & $\begin{array}{c}368904 \\
(-5.8)\end{array}$ \\
\hline Jordan & $23818(5.5)$ & $26425(2.3)$ & $28840(2.6)$ & $31015(2.7)$ & $33678(2.8)$ \\
\hline Malaysia & $202251(-1.5)$ & $247534(7.4)$ & $289259(5.1)$ & $\begin{array}{c}305033 \\
(5.6)\end{array}$ & $\begin{array}{c}312435 \\
(4.7)\end{array}$ \\
\hline Nigeria & $169481(6.9)$ & $369062(7.8)$ & 411744 (4.9) & $\begin{array}{c}462979 \\
(4.3)\end{array}$ & $\begin{array}{c}521803 \\
(5.4)\end{array}$ \\
\hline Pakistan & $167875(2.8)$ & $177166(1.6)$ & $213686(2.8)$ & $\begin{array}{c}224880 \\
\quad(4.0)\end{array}$ & $\begin{array}{c}236625 \\
(6.1)\end{array}$ \\
\hline Saudi Arabia & $429098(1.8)$ & $526811(7.4)$ & 669507 (8.6) & $\begin{array}{c}733956 \\
(5.8)\end{array}$ & $\begin{array}{c}745273 \\
(3.8)\end{array}$ \\
\hline Turkey & $614554(-4.8)$ & $731168(9.2)$ & 774754 (8.8) & $\begin{array}{c}788863 \\
(2.1)\end{array}$ & $\begin{array}{c}820207 \\
(4.0)\end{array}$ \\
\hline $\begin{array}{c}\text { United Arab } \\
\text { Emirates }\end{array}$ & $254803(-4.8)$ & $287422(1.7)$ & 348595 (3.9) & $\begin{array}{c}383799 \\
(4.4)\end{array}$ & - \\
\hline
\end{tabular}
pasar potensial.

Tabel 4 PDB negara pasar ekspor Indonesia di OKI tahun 2009-2013 (juta US\$)

Sumber : Worldbank (2014)

Langkah awal pada penelitian ini yaitu melakukan identifikasi komoditas ekspor Indonesia ke OKI selama sepuluh tahun terakhir (2004-2013). Didapatkan hasil bahwa ternyata terdapat lebih dari seribu jenis komoditi yang telah diekspor ke negara anggota OKI. Dari sekian banyak komoditi tersebut, maka dilakukan pemilahan komoditi yang akan diteliti yaitu hanya sebanyak lima belas macam komoditas dengan nilai ekspor yang paling besar di tahun 2012.

Hasil analisis RCA menunjukkan bahwa 86.7 persen komoditas ekspor Indonesia ke OKI di tahun terakhir penelitian yaitu pada tahun 2013 memiliki nilai RCA diatas satu. Hal ini menunjukkan adanya keselarasan antara besaran nilai ekspor dengan kemampuan komoditi tersebut untuk bersaing dengan komoditi yang sama dari negara lain. Tabel 3 menunjukkan 
bahwa komoditi yang berdaya saing tinggi di pasar OKI didominasi oleh kelompok produk lemak dan minyak hewani atau nabati, kemudian produk pertambangan serta produk-produk kimia.

Secara spesifik, nilai ekspor terbesar Indonesia ke OKI masih dikuasai oleh palm oil \& its fraction (HS 1511). Pada tahun 2012, ekspor minyak kelapa sawit mencapai puncaknya sebesar US\$ 4.8 miliar. Hasil analisis RCA minyak kelapa sawit pada tahun 2013 adalah 32.50. Selain minyak kelapa sawit, sebagian besar komoditi yang diuji memiliki daya saing tinggi. Hanya dua komoditi yang memiliki nilai RCA di bawah satu yaitu cars (incl. station wagon) dengan nilai RCA 0.98 dan petroleum oils, not crude dengan nilai RCA 0.27 .

Tabel 5 Hasil analisis RCA, IIT dan EPD

\begin{tabular}{|c|c|c|c|c|c|}
\hline No & Kode HS & Nama Komoditi & RCA & IIT & EPD \\
\hline 1 & 1511 & Palm oil \& its fraction & 32.50 & 1.59 & Rising Star \\
\hline 2 & 2701 & $\begin{array}{l}\text { Coal; briquettes, ovoids \& similar } \\
\text { solid fuels manufactured from coal }\end{array}$ & 13.55 & 0.11 & Falling Star \\
\hline 3 & 2713 & $\begin{array}{l}\text { Petroleum coke, petroleum bitumen } \\
\& \text { other residues of petroleum oils }\end{array}$ & 29.79 & 19.45 & Rising Star \\
\hline 4 & 8703 & Cars (incl. station wagon) & 0.98 & 13.24 & Falling Star \\
\hline 5 & 2710 & Petroleum oils, not crude & 0.27 & 10.48 & Falling Star \\
\hline 6 & 4802 & $\begin{array}{l}\text { Uncoated paper for writing, } \\
\text { printing etc. }\end{array}$ & 14.62 & 0.72 & Falling Star \\
\hline 7 & 1513 & $\begin{array}{l}\text { Coconut (copra),palm } \\
\text { kernel/babassu oil \& their fractions }\end{array}$ & 37.05 & 0.40 & Lost opportunity \\
\hline 8 & 5407 & Woven fabrics of synth. filam yarn & 4.52 & 2.40 & Falling Star \\
\hline 9 & 2711 & Petroleum gases & 2.60 & 29.14 & Rising Star \\
\hline 10 & 4011 & New pneumatic tires, of rubber & 2.20 & 4.18 & Rising Star \\
\hline 11 & 4412 & $\begin{array}{l}\text { Plywood, veneered panels and } \\
\text { similar laminated wood }\end{array}$ & 11.51 & 0.53 & Falling Star \\
\hline 12 & 3823 & $\begin{array}{l}\text { Industrial monocarboxylic fatty } \\
\text { acid }\end{array}$ & 31.59 & 26.97 & Rising Star \\
\hline 13 & 3401 & $\begin{array}{l}\text { Soap; organic surface-active } \\
\text { preparations for soap use }\end{array}$ & 13.07 & 4.17 & Rising Star \\
\hline 14 & 8001 & Unwrought tin & 31.72 & 5.39 & Rising Star \\
\hline 15 & 7403 & $\begin{array}{l}\text { Refined copper and copper alloys, } \\
\text { unwrought }\end{array}$ & 2.63 & 7.30 & Lost opportunity \\
\hline
\end{tabular}

\section{Analisis Intra Industry Trade (IIT)}

Hasil analisis terhadap derajat integrasi perdagangan lima belas komoditi penyumbang ekspor terbesar Indonesia ke OKI menunjukkan bahwa tidak ada satupun dari komoditi ekspor tersebut yang memiliki derajat integrasi yang kuat atau sangat kuat. Berdasarkan klasifikasi IIT oleh Austria (2004), beberapa komoditi hanya memiliki tingkat integrasi sedang dengan nilai IIT berkisar antara 25.00-49.99. Produk bahan bakar mineral seperti petroleum coke, petroleum bitumen \& other residues of petroleum oils (HS 2713), petroleum gases (HS 2711) serta produk kimia industrial monocarboxylic fatty acid (HS 3823) memiliki tingkat derajat integrasi sedang. Hal ini mengindikasikan bahwa perdagangan antara Indonesia dan negara OKI adalah perdagangan satu arah. 


\section{Analisis Export Product Dynamic (EPD)}

Hasil analisis EPD menunjukkan terdapat tujuh komoditi yang berada pada posisi rising star yaitu palm oil \& its fraction (HS 1511), petroleum coke, petroleum bitumen \& other residues of petroleum oils (HS 2713), petroleum gases (HS 2711), new pneumatic tires, of rubber (HS 4011), industrial monocarboxylic fatty acid (HS 3823), soap; organic surface-active preparations for soap use (HS 3401) dan unwrought tin (HS 8001). Posisi rising star merupakan posisi yang paling tinggi dari matriks EPD. Posisi ini menggambarkan kinerja perdagangan ekspor yang cepat dan dinamis dimana tingkat pertumbuhan ekspor dari Indonesia terus meningkat dan pertumbuhan pangsa ekspor di pasar OKI juga mengalami peningkatan sehingga komoditi yang termasuk kategori ini berada pada level yang kompetitif (Bappenas, 2009).

Komoditas ekspor Indonesia yang lain berada pada posisi falling star dan lost opportunity. Beberapa komoditas yang termasuk kategori falling star adalah coal; briquettes, ovoids \& similar solid fuels manufactured from coal (HS 2701, cars (incl. station wagon) (HS 8703), petroleum oils, not crude (HS 2710), uncoated paper for writing, printing etc. (HS 4802), woven fabrics of synth. filam yarn (HS 5407) dan plywood, veneered panels and similar laminated wood (HS 4412). Pertumbuhan ekspor selama sepuluh tahun terakhir pada produk ini masih positif, namun dari segi permintaan mengalami penurunan. Sedangkan komoditas yang termasuk kategori lost opportunity yaitu coconut (copra),palm kernel/babassu oil \& their fractions (HS 1513) dan refined copper and copper alloys, unwrought (HS 7403). Kedua komoditi ini terindikasi kehilangan pangsa pasarnya di negara-negara OKI. Pertumbuhan ekspor selama periode 2004-2013 untuk kedua produk tersebut menunjukkan trend yang negatif dengan coconut (copra),palm kernel/babassu oil \& their fractions (HS 1513) negatif 0.14 dan refined copper and copper alloys, unwrought (HS 7403) negatif 0.16 .

\section{Analisis Faktor Penentu Ekspor Komoditas Unggulan Indonesia ke OKI}

Hasil signifikansi koefisien menggunakan data panel terhadap masing-masing komoditi dalam periode waktu sepuluh tahun tersaji pada Tabel 4. Dari hasil analisis tersebut dapat diambil kesimpulan bahwa model yang paling tepat untuk menganalisis faktor penentu ekspor komoditas yang berdaya saing adalah model random effects berdasarkan hasil uji Hausman.

Tabel 6 Hasil uji koefisien faktor-faktor penentu ekspor komoditas unggulan Indonesia ke OKI

\begin{tabular}{lccccc}
\hline \multirow{2}{*}{ Variabel } & \multicolumn{5}{c}{ Komoditi } \\
\cline { 2 - 6 } & $\begin{array}{c}\text { HS 1511 } \\
\text { Palm Oil }\end{array}$ & $\begin{array}{c}\text { HS 3401 } \\
\text { Soap }\end{array}$ & $\begin{array}{c}\text { HS 3823 } \\
\text { Fatty acid }\end{array}$ & $\begin{array}{c}\text { HS 4011 } \\
\text { Tyre }\end{array}$ & $\begin{array}{c}\text { HS 4802 } \\
\text { Paper }\end{array}$ \\
\hline C & 17.87145 & 1.170378 & 14.87589 & 10.51476 & 9.365621 \\
LN_PDBCAP $_{\mathrm{I}}$ & $2.277467^{\star *}$ & $1.446491^{\star \star}$ & $3.216865^{\star \star}$ & $0.552070^{\star *}$ & $0.843948^{\star \star}$ \\
LN_PDBCAP $_{\mathrm{J}}$ & $-0.803975^{\star *}$ & $0.905145^{\star \star}$ & $-1.350995^{\star \star}$ & $0.348320^{\star *}$ & 0.231035 \\
LN_PDBCAPD $_{\mathrm{ij}}$ & -0.084360 & $-0.575602^{\star *}$ & 0.068787 & -0.093404 & -0.072095 \\
LN_RER $_{\mathrm{ij}}$ & 0.123704 & -0.108333 & 0.229008 & $0.122583^{* *}$ & -0.118081
\end{tabular}




\begin{tabular}{lccccc}
\hline \multirow{2}{*}{ Variabel } & \multicolumn{5}{c}{ Komoditi } \\
\cline { 2 - 6 } & $\begin{array}{c}\text { HS 1511 } \\
\text { Palm Oil }\end{array}$ & $\begin{array}{c}\text { HS 3401 } \\
\text { Soap }\end{array}$ & $\begin{array}{c}\text { HS 3823 } \\
\text { Fatty acid }\end{array}$ & $\begin{array}{c}\text { HS 4011 } \\
\text { Tyre }\end{array}$ & $\begin{array}{c}\text { HS 4802 } \\
\text { Paper }\end{array}$ \\
\hline LN_ECODIST $_{\mathrm{ij}}$ & $-0.845064^{* *}$ & -0.027024 & $-1.305079^{* *}$ & -0.107292 & 0.080954 \\
TRF $_{\mathrm{j}}$ & $-0.106219^{* *}$ & 0.028560 & $-0.142418^{* *}$ & -0.024840 & -0.041668 \\
LANG & 0.080290 & 2.349474 & 0.553813 & $1.115996^{\star *}$ & $1.896635^{\star *}$ \\
Model & REM & REM & REM & REM & REM \\
R-squared & 0.539795 & 0.347278 & 0.608312 & 0.588812 & 0.566008 \\
Adjusted & 0.504779 & 0.297615 & 0.577505 & 0.557526 & 0.532987 \\
R-squared & 0.000000 & 0.000001 & 0.000000 & 0.000000 & 0.000000 \\
Prob(F-statistic) & 1.021190 & 1.084399 & 1.401438 & 0.858041 & 1.023983 \\
DW Stat & & & & & \\
\hline
\end{tabular}

** Signifikan pada taraf nyata $5 \%$

* Signifikan pada taraf nyata $10 \%$

\section{Pendapatan per kapita}

Variabel pendapatan per kapita negara Indonesia memiliki pengaruh yang positif dan signifikan terhadap semua komoditi terpilih pada taraf nyata 5 persen. Peningkatan pendapatan masyarakat Indonesia akan mendorong peningkatan ekspor komoditi palm oil and its fraction (HS 1511), soap; organic surface-active preparations for soap use (HS 3401), industrial monocarboxylic fatty acid (HS 3823), new pneumatic tires (HS 4011) dan uncoated paper for writing, printing etc (HS 4802). Tingginya tingkat pendapatan negara pengekspor ini mengindikasikan terjadinya peningkatan produksi sehingga ketersediaan barang untuk ekspor meningkat (Lehmann, 2003)

Dari segi pendapatan per kapita negara importir, hasil estimasi model gravitasi bervariasi antar komoditi. Komoditi seperti soap; organic surfaceactive preparations for soap use (HS 3401) dan new pneumatic tires (HS 4011) memiliki pengaruh yang positif dan signifikan. Hal ini mengindikasikan terjadinya peningkatan impor seiring dengan peningkatan pendapatan negara importir. Sebaliknya, untuk komoditi palm oil dan industrial monocarboxylic fatty acid terjadi penurunan ekspor ketika pendapatan per kapita importir meningkat. Hal ini dapat disebabkan kedua komoditi tersebut sudah termasuk pada kategori barang inferior bagi negara-negara anggota OKI terutama yang memiliki pendapatan per kapita yang sangat tinggi, sehingga terjadi penurunan permintaan seiring dengan peningkatan pendapatan masyarakatnya. Masyarakat dengan tingkat pendapatan yang tinggi akan memilih produk sejenis dari negara lain yang memiliki kualitas yang lebih baik.

\section{Perbedaan PDB per kapita (GDP differences)}

Perbedaan pendapatan per kapita digunakan untuk mengetahui pola perdagangan antara Indonesia dengan negara anggota OKI. Variabel ini bertujuan untuk menguji efek Linder yang menyebutkan bahwa perdagangan bilateral akan memiliki dampak yang lebih besar ketika PDB per kapita negara-negara tersebut memiliki tingkatan yang mirip/sama. Nilai koefisien yang negatif dan signifikan pada komoditi soap; organic surfaceactive preparations for soap use (HS 3401) telah sesuai dengan efek Linder 
dimana perbedaan pendapatan per kapita yang tinggi akan berpengaruh negatif terhadap ekspor dan setiap kenaikan perbedaan pendapatan per kapita sebesar 1 persen akan menurunkan nilai ekspor soap sebesar 0.57 persen (ceteris paribus).

\section{Nilai tukar riil}

Hasil estimasi untuk variabel nilai tukar riil menunjukkan bahwa komoditi unggulan ekspor Indonesia ke OKI hampir semuanya tidak terpengaruh oleh nilai tukar. Hanya komoditi new pneumatic tyres (HS 4011) yang terpengaruh oleh nilai tukar. Koefisien estimasi menunjukkan bahwa nilai tukar riil berpengaruh signifikan dan positif pada taraf nyata 5 persen. Hubungan yang positif dapat diartikan bahwa bila nilai tukar mengalami penurunan atau terjadi depresiasi, maka ekspor akan meningkat (Nguyen, 2010). Nilai koefisien HS 4011 sebesar 0.12258 memiliki arti bahwa jika terjadi depresiasi nilai tukar sebesar 1 persen, maka akan terjadi peningkatan nilai ekspor sebesar 0.12 persen (ceteris paribus).

Variabel nilai tukar riil Indonesia terhadap negara-negara anggota OKI tidak memiliki pengaruh yang banyak bagi sebagian besar komoditas. Hal ini dikarenakan tingkat volatilitas mata uang Indonesia dan negara-negara OKI relatif stabil. Beberapa negara anggota OKI bahkan memiliki nilai tukar yang tidak berubah dalam periode tahun 2004 sampai dengan 2013 yaitu negara Jordan, Saudi Arabia dan Uni Emirat Arab

\section{Jarak ekonomi}

Variabel jarak yang merupakan proksi dari biaya transportasi memiliki pengaruh negatif terhadap ekspor (Di Mauro, 2001). Komoditi soap; organic surface-active preparations for soap use (HS 3401), new pneumatic tires (HS 4011) dan uncoated paper for writing, printing etc (HS 4802) tidak terpengaruh oleh jarak ekonomi, hanya dua komoditi yaitu palm oil \& its fraction (HS 1511) dan industrial monocarboxylic fatty acid (HS 3823) yang terpengaruh secara signifikan. Setiap adanya peningkatan jarak ekonomi sebesar 1 persen akan menambah biaya transportasi sehingga akan menurunkan nilai ekspor komoditi palm oil sebesar 0.84 persen dan komoditi industrial monocarboxylic fatty acid sebesar 1.30 persen.

\section{Tarif}

Pengaruh tarif pada suatu perdagangan dapat menambah biaya yang dikeluarkan oleh eksportir maupun importir sehingga dapat menyebabkan harga menjadi mahal. Sebagian besar komoditas unggulan ekspor Indonesia ke OKI terpengaruh negatif oleh tarif. Dua komoditi unggulan yaitu palm oil \& its fraction (HS 1511) dan industrial monocarboxylic fatty acid (HS 3823) memiliki koefisien tarif yang negatif dan berpengaruh signifikan pada taraf nyata 5 persen. Pada komoditi palm oil, setiap kenaikan tarif sebesar 1 persen akan menurunkan nilai ekspor palm oil Indonesia ke negara anggota OKI sebesar 0.11 persen, sedangkan pada komoditi industrial monocarboxylix fatty acid, setiap kenaikan tarif sebesar 1 persen akan menurunkan nilai ekspor sebesar 0.14 persen (ceteris paribus).

\section{Kesamaan bahasa}

Faktor kesamaan bahasa memiliki pengaruh yang positif pada semua komoditas unggulan ekspor Indonesia ke OKI. Negara yang memiliki kemiripan dalam bahasa akan memiliki potensi yang lebih dalam perdagangan bilateral (Binh, 2013). Hasil estimasi yang signifikan dan berpengaruh nyata 
diperoleh pada komoditi new pneumatic tyre (HS 4011) dan uncoated paper for writing, printing etc (HS 4802). Faktor bahasa akan meningkatkan ekspor komoditi new pneumatic tyre (HS 4011) sebesar 205 persen $\left(\mathrm{e}^{1,11}-1 \approx 2.05\right)$, sedangkan untuk komoditi uncoated paper for writing, printing etc (HS 4802) sebesar 566 persen.

\section{KESIMPULAN DAN SARAN}

\section{Kesimpulan}

Berdasarkan hasil analisis dalam penelitian ini, dapat diambil beberapa kesimpulan terkait dengan kinerja perdagangan Indonesia ke OKI, yaitu :

1. Ekspor terbesar Indonesia ke pasar OKI terfokus pada 10 negara selaras dengan potensi ekonomi yang ada berdasarkan pertumbuhan PDB yang positif dan tingkat populasinya.

2. Terdapat lima belas besar komoditi yang menjadi andalan ekspor Indonesia ke OKI dengan komoditi palm oil \& its fraction (HS 1511) sebagai komoditi yang paling besar nilai ekspornya.

3. Dari lima belas besar komoditi penyumbang ekspor terbesar, terdapat 86.7 persen komoditi dengan nilai RCA lebih dari satu. Hal ini menunjukkan bahwa sebagian besar komoditas Indonesia dapat bersaing di pasar OKI.

4. Tingkat integrasi perdagangan Indonesia dan OKI masih termasuk ke dalam kategori perdagangan satu arah dengan nilai IIT yang paling tinggi hanya pada derajat integrasi sedang. Sebagian besar komoditas ekspor Indonesia ke OKI adalah produk pertanian dan pertambangan berupa bahan mentah (raw material) yang selama ini menjadi keunggulan dari Indonesia, sedangkan perkembangan industri antar negara tersebut belum berkembang dan masih perlu ditingkatkan agar tercipta perdagangan dua arah.

5. Kinerja perdagangan Indonesia apabila dilihat dari market position komoditinya sebagian besar memiliki performa yang baik. Dari lima besar komoditas ekspor tertinggi, menghasilkan tujuh komoditi berstatus rising star (pertumbuhan pangsa pasar dan pertumbuhan ekspor relatif tinggi), enam komoditi berstatus falling star (pertumbuhan pasar relatif rendah namun pertumbuhan ekspor dari Indonesia relatif tinggi) dan hanya dua komoditi berstatus loss opportunity (pertumbuhan permintaan yang relatif tinggi namun pertumbuhan ekspor dari Indonesia masih rendah).

6. Variabel-variabel yang menjadi faktor penentu ekspor komoditas unggulan menunjukkan bahwa variabel pendapatan per kapita Indonesia yang merupakan proksi dari produksi dalam negeri berpengaruh nyata dan signifikan untuk semua komoditi. Variabel lain yang memiliki pengaruh signifikan adalah pendapatan per kapita pengimpor, perbedaan pendapatan per kapita, jarak ekonomi, tarif dan kesamaan bahasa yang nilai dan tingkat signifikansinya berbedabeda untuk tiap komoditi.

\section{Saran}

1. Perlu dilakukan peningkatan daya saing komoditas yang memiliki nilai RCA dibawah satu, sehingga persentase komoditas ekspor Indonesia yang berdaya saing di pasar ekspor OKI semakin tinggi.

2. Untuk memperbaiki tingkat integrasi perdagangan Indonesia dan negara anggota OKI, maka perlu 
dilakukan hilirisasi atau olahan terhadap komoditi dari Indonesia. Kebijakan hilirisasi komoditi dapat diterapkan tidak hanya pada sektor mineral dan pertambangan (minerba) tetapi juga sektor-sektor lainnya. Kebijakan hilirisasi dapat mendorong industri untuk mengekspor komoditas olahan, tidak hanya komoditi dalam bentuk bahan mentah, sehingga nilai tambah komoditi tersebut semaikin tinggi. Pemerintah dapat memberikan kemudahan atau insentif bagi para pengusaha untuk mendirikan industri pengolahan salah satunya yaitu dengan memberikan keringanan pajak dalam jangka waktu tertentu.

3. Variabel pendapatan per kapita negara importir yang berpengaruh negatif terhadap komoditi palm oil \& its fraction (HS 1511) dan industrial monocarboxylic fatty acid (HS 3823) mengindikasikan terjadinya penurunan permintaan ketika pendapatan per kapita masyarakat negara importir semakin tinggi memberikan implikasi bahwa kedua komoditi perlu diperbaiki kualitasnya sehingga sesuai dengan standard dan mengikuti selera konsumen yang semakin meningkat.

4. Hasil analisis Export Product Dynamics (EPD) untuk komoditas terpilih, memperlihatkan bahwa masih ada produk yang termasuk ke dalam kategori loss opportunity. Kondisi ini sangat disayangkan, karena pertumbuhan pangsa pasar untuk komoditi kategori loss opportunity sebenarnya meningkat, tetapi pertumbuhan ekspor dari Indonesia mengalami penurunan. Penurunan ekspor ini dapat terjadi karena peningkatan konsumsi dalam negeri ataupun oleh adanya persaingan harga, sehingga khusus untuk komoditi dengan kategori loss opportunity perlu dilakukan strategi efisiensi dalam kegiatan produksi dan mendorong peningkatan produksi. Diharapkan dengan strategi ini komoditas tersebut dapat memenuhi kecukupan konsumsi di dalam negeri dan dapat bersaing kembali dengan produk sejenis dari negara lain, sehingga terjadi peningkatan status menjadi rising star.

5. Biaya perdagangan yang lain selain biaya transportasi adalah tarif. Hasil analisis model gravitasi menunjukkan tarif yang berlaku di Organisasi Kerjasama Islam hampir semuanya memiliki pengaruh yang negatif dan beberapa komoditi terpengaruh secara signifikan, sehingga pada saat perundingan kerjasama perdagangan perlu lebih difokuskan pada penurunan tarif bea masuk agar lebih mempermudah ekspor komoditas dari Indonesia.

6. Untuk penelitian selanjutnya, dapat dilakukan penambahan variabel harga tiap komoditi. Penambahan variabel ini akan sangat menentukan dari segi permintaan. Oleh karena adanya keterbatasan informasi mengenai harga per komoditi, maka dapat dimasukkan variabel harga per volume ekspor atau unit price

\section{DAFTAR PUSTAKA}

Austria MS. 2004. The pattern of intra ASEAN trade in the priority goods sectors. REPSF Project No. 03/006e. Final Main Report.

Bappenas. 2009. Perdagangan dan investasi di Indonesia : Sebuah catatan tentang daya saing dan tantangan ke depan.

Binh DTT, Duong NV, Cuong HM. 2013. Applying gravity model to analyze trade activities of Vietnam. 
FREIT Working Paper December 2013.

Di Mauro F. 2001. Economic integration between the EU and the CEECs : A sectoral study. Center For European Policy Studies. Working document no. 165, April 2001.

Estherhuizen D. 2006. Measuring and analyzing competitiveness in the agribusiness sector: Methodological and analytical framework. University of Pretoria.

Kementerian Perdagangan. 2011. Kajian kebijakan pengembangan diversifikasi pasar dan produk ekspor. Pusat Kebijakan Perdagangan Luar Negeri. Badan Pengkajian dan Pengembangan Kebijakan Perdagangan.
2013.

Statistik perdagangan luar negeri Indonesia. DJPEN, Kementerian Perdagangan.

Lehmann FN, Zarzoso IM. 2003. Augmented gravity model : An empirical application to MercosurEuropean Union trade flows. Journal of Applied Economics, Vol VI no. 2. November 2003.

Nguyen, BX. 2010. The determinants of Vietnamese export flows : Static and dynamic panel gravity approaches. International Journal of Economics and Finance Vol. 2 No. 4. November 2010.

Sharma K. 2004. Horizontal and vertical intra industry trade in TransTasman bilateral trade. Journal of Economic Integration. 19(3), September 2004;590-603. 